\title{
Microorganisms affecting Post-Harvest Sucrose Losses in Sugarcane
}

\author{
Varucha Misra $^{1 *}$, A.K. Mall ${ }^{1}$, A.D. Pathak ${ }^{1}$, S. Solomon ${ }^{2}$ and Ram Kishor ${ }^{1}$ \\ ${ }^{1}$ ICAR-Indian Institute of Sugarcane Research, Lucknow- 226 002, India \\ ${ }^{2}$ Chandra Shekhar Azad Agricultural University, Kanpur-208 002, India \\ *Corresponding author
}

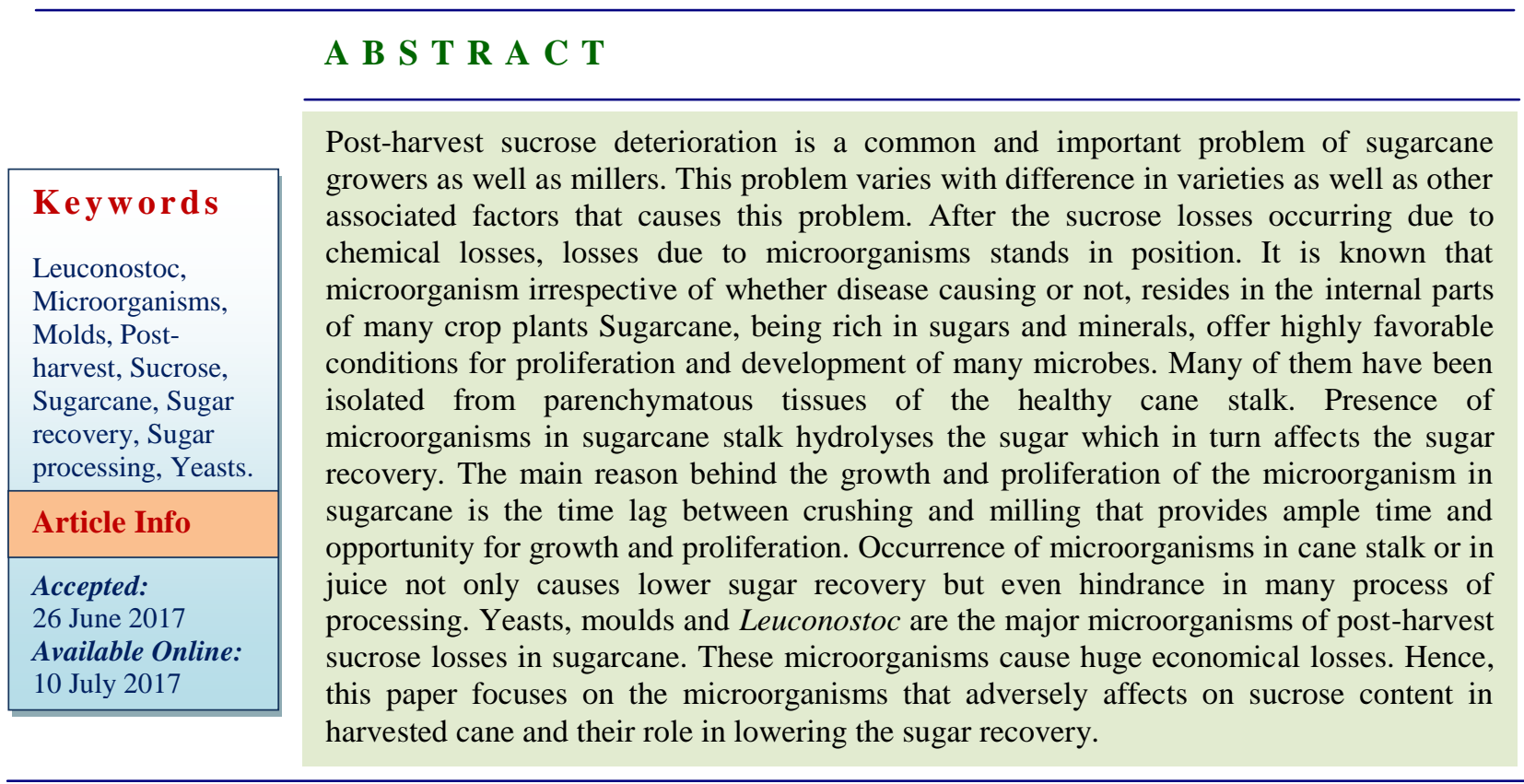

\section{Introduction}

Sucrose losses after cane harvest is one of the most important problems in sugarcane crop particularly for millers and farmers. Loss in sucrose after harvesting causes low sugar recovery in mills. There are a large number of factors associated with low sugar recovery such as varietal type, atmospheric conditions, time lag, etc. Sucrose losses occurring in postharvest sugarcane are generally of four types(i) Chemical loss: Occur due to changes in $\mathrm{pH}$ and temperatures (ii) Microbial loss: Occur due to consumption of sucrose by its growth and proliferation (iii) Enzymatic loss: Occur due to microbial and invertase present in cells of sugarcane stalk (iv) Indirect losses occurring due to the formation of metabolites from microorganisms that invade in sugarcane or during processing. The major losses of sucrose after chemical loss in post-harvest sugarcane are of from microorganisms. Products formed from sugarcane as well in sugar mills are the most nutritive source for growth and proliferation of microorganisms. These microbes grow at a rapid pace and forms products that deteriorate sucrose of the cane stalk thereby hindering the production of final product, sugar (Solomon, 2009; Misra et al., 2016). Besides, the presence of 
microorganisms inside sugarcane stalk or in cane juice at mills also causes problems during processing. Even the boiling of juice generally performed at clarification step may not help in elimination of microbes that had entered either in cane stalk or in juice during processing. In spite there are certain microorganisms that grow at clarifier step and further accentuates in the later processes (Solomon, 2000).

The invasion of microorganisms in sugarcane stalks is well known through cut ends of the harvested canes. Once the microorganisms are entered into the juice rich region they rapidly proliferate. When this microorganism's affected cane is processed in mills it enters into the primary juice collecting tanks. It has been reported on the basis of environmental conditions, primary juice contains $10^{6}$ to $10^{9}$ cfu per ml of microorganisms approximately. But this number may vary qualitatively from place to place and season to season. Studies have shown that cold climate favors yeast growth and proliferation while Lactobacillus predominates in summer seasons. Both these microbes are known to grow and consume sugar at a very fast pace and it is believed that $>1$ per cent of cane sugar is lost during the time lag of harvesting and milling. Furthermore, various metabolites are formed by these microbes which results in hindrance in processing. This hindrance affects the sugar recovery of the mills and also negatively affects the quality of sugar obtained. Thus, this paper focuses on the microorganisms that adversely affects on sucrose content in harvested cane and their role in lowering the sugar recovery.

\section{Sources of microbial contamination}

The origin of the contaminating organisms has been traced to the soil adhering to cane stalk and leaves. Small numbers of organisms are detected on the surface of green and burnt cane, but not inside the stalk. The cut ends of cane stalk become infected majorly with a mucous producing bacterium, Leuconostoc sp., at the time of harvest by contact with contaminated sources such as cane cutter's machetes, soil and the epiphytic flora of the plant. It is known that the infection of Leuconostoc rapidly penetrates the stalk and colonizes the internal tissue. Multiplications of these bacteria were rapidly seen in harvested canes. These bacteria posses' characteristic exponential growths curve which later on shows slight declination. The maximum count was reported to be $10^{7}-10^{-8}$ cells/ml which is achieved within 3 to 4 days after cane was harvested (Solomon, 2009; Misra et al., 2016). The invasion of microorganisms does not end up at harvesting time; however, it may occur even during cane processing in sugar mills. Sometimes the microorganisms generally found on the cane stalks of sugarcane are washed off during the cane processing in sugar mills into the juice extracted from it. The microorganisms on reaching the extracted juice found favorable conditions for its growth and proliferation as juice is rich in both organic and inorganic nutrients. There are various sites in cane processing where microorganisms can easily invade and proliferate. Firstly, there is a condition of aeration which is favorable for the growth of microorganisms at the time when juice falls from the mills. Secondly, there are various points during milling process where flow of juice is either stagnated or at a slow pace wherein the microorganisms find favorable time for growth and proliferation (Solomon, 2000; 2009; Misra et al., 2016). Besides, there is number of sites favoring growth and proliferation of microorganisms during milling by consuming the sucrose extracted from cane stalks. These are:

(i) Recycling of wash water: The recycling of wash water for cleaning the canes help in 
contamination with microorganisms even in healthy canes. The used washed water carries a sizeable number of microorganisms particularly dextran producing microorganisms.

(ii) Contaminated juice collecting troughs: These containers are the prime areas in the sugar mills for invasion of microorganisms particularly, multiplication of Leuconostoc sp.

(iii) Areas behind juice screens: These areas behind screens are more likely to harbor dextran producing microorganisms. Even the juice screens are major source of bacterial infection.

(iv) Dilute juice tanks: These tanks are sites of microbial contamination as they receive contaminated juices.

(v) Pipe lines and valves holding unlimed juice are also the sites where microbial contamination takes place.

\section{Factors influencing growth of microorganisms in harvested sugarcane}

There are many factors that influence the infestation and proliferation of microorganisms (Fig. 1) in enhancing the post harvest sucrose losses which leads to low sugar recovery (Duncan and Colmer, 1964; Bevan and Bond, 1971). These are as follows:

(1) Physical damage on cane: Cane possessing physical damage provides favorable conditions for the growth of microorganisms. This physical damage in harvested canes may be due to the mechanical harvesting or due to the sudden abrupt changes of the atmospheric temperatures or through the growth cracks, etc.

(2) Atmospheric conditions prevailing after harvest of cane: These conditions influence the growth and proliferation of microbes, particularly in the stale cane. It has been reported that in wet, warm weathers, the juice extracted from cane stubble may had higher amount of microorganisms (about $10^{9}, 10^{6}$ and $10^{6}$ of bacteria, yeasts and moulds respectively in per gram of cane) (Mayeux, 1960). Origin of these could be from soil as well as decaying plant material in vicinity; however, no constant association of specific microorganisms in sugarcane soil rhizosphere had been observed. Occurrence of higher amount of microorganisms and their survival rate has been observed in conditions when there is heavy rainfall and high humidity especially for bacteria like Leuconsotoc sp. which under such conditions leads to high amount of dextrans (Misra et al., 2016).

(3) Time lag between harvesting and milling: The major factor of occurrence of high microbiological losses in harvested sugarcane is the time gap between harvesting and milling. This time gap could extend from few to several days (Solomon, 2009). Solomon (2000) and Solomon (2009) had showed that harvested cane starts deteriorating its sucrose content and such losses increases with the increase in time lag. Such a time lag makes cane more prone to microbial invasion as the juice extruding out through cut ends nurture microorganisms (Bevan and Bond, 1971; Solomon, 2000). Higher microbial invasion was also being observed in canes that have grown under drought and water logging conditions and the rate of microbial invasion with the increase in time in harvested canes of such conditions was revealed to be relatively more than the normal conditions (Misra et al., 2016a; 2016b).

(4) Damage duration in the harvested canes: It is well understandable that longer exposure of internal tissues of cane stalk before it is been crushed higher will be the 
proliferation as well as growth rate of associated microorganisms resulting in relatively more sucrose losses in harvested sugarcane. These enhanced sucrose losses in harvested canes result in relatively much lower sugar recovery.

\section{Microorganisms in standing sugarcane}

Species of Flavobacterium, Lactobacillius, Xanthomonas, Enterobacter (Klebsiella pneumonia), Pseudomonas, Erwinia, Bacillus, Leuconostoc and Cornybacterium are the most persistent occurring bacteria on cane leaves and stalks of healthy ones (Suman et al., 2000; Nunez and Colomer, 1968). Mayeux (1960) and Duncan and Colmer (1964) had showed that the population rate of these microorganisms vary from $10^{4}-10^{8}$ per $g$ of cane. Out of all these microorganisms, some of them are pathogenic while some are non pathogenic. These microorganisms may facilitate post-harvest sucrose deterioration. Yeast, Leuconostoc and some acid producers (basically rod shaped bacteria) are some of the microbes that infest the cane stalks as soon as cane is harvested. After infestation, these bacteria reach the internal tissues of cane stalks where sucrose is hydrolysed into monosaccharide like glucose and fructose. Solomon et al., (2006) had showed that yeasts, Leuconostoc, Xanthomonas and Aerobacter were present at the cut or damaged sites of the cane. The latter three microorganisms have the potential to convert sucrose into a polyssacharide, dextran (mucoid material). The conversion of sucrose into dextran indicates that sugarcane has deteriorated its sucrose content. Kulkarni and Kulkarni (1987) had found that Actinomyces, Penicillium and acid producing Streptomyces are also certain microorganisms which are found on harvested cane and these microorganisms contribute to the post-harvest sucrose losses in sugarcane. Besides, yeasts and moulds $\left(10^{3}-10^{4} / \mathrm{g}\right)$ were also observed
(Shehata, 1960; Tilbury, 1970). So far approximately fifty different microorganisms have been reported on green cane while seventeen on the burnt cane which cause huge sucrose losses in post-harvest sugarcane (Solomon et al., 2000; 2006).

Microbial sucrose losses were much higher in comparison the losses by biochemical and chemical means.

\section{Microorganisms in processing of sugars}

As cane processing involves number of steps for obtaining the final product, sugar, there are various sites where microbes have the probability of invading either cane or in primary and mixed juices in sugar mills. The various associated microorganisms in sugar processing are mentioned in table 1 .

However, there are basically three major groups of microorganisms that play significant role in sugarcane deterioration. These are molds, fungi, osmophilic yeasts (frequently Torulae) and sporogenous bacteria, particularly L. mesenteroides group.

\section{Moulds}

Moulds may be originally being invaded either into sugarcane after harvest or found on to the surface of cane. These microbes are able to survive during processing of cane in sugar mills. In sugar processing at mills, these are frequently observed generally at centrifugation step of processing. Kopoloffs (1920) identified species of mold fungi that were found in raw sugars. This caused huge amount of cane deterioration by action of these moulds, of which Aspergillus niger and A. sydowii were the most common. However, Sherwood and Hines (1950) found that Aspergillus glacus has great cane deterioration potential. Moulds are not that important as compared to other microbes as 
they are active only in dilute molasses films. During crystallization, centrifugation or drying stages of sugar processing, molds such as, Aspergillus and Penicillium spp. may pollute the products (Kumar and Singh, 2012). Silva et al., (2016) had showed that in cane juice the average amount of aerobic mesophilic, molds and yeast were 6.26 and $5.20 \log$ CFU/mL, respectively. Gandra et al., (2007) and Prati (2004) had reported that the presence of aerobic mesophilic microorganisms (mesophilic microbial load 6 $\log \mathrm{CFU} / \mathrm{mL}$ and $7 \log \mathrm{CFU} / \mathrm{mL}$ ) of may activate the negative changes in juice thereby leading to its deterioration.

\section{Yeasts}

Similar to molds, yeasts also invade into the sugarcane stalk or on the cane surface. These also able to exist even during the process of cane into sugar. Another similarity with molds is that the centrifugation step of processing is also its site of occurrence for yeast. These microbes although are among the least essential factor responsible for postharvest sugarcane deterioration yet, there have been some instances recorded of cane deterioration due to osmophilic yeasts (James, 1993). The invasion of yeasts in sugarcane occurs through the longitudinal split in sheathed leaf base (Ingram, 1957). Scarr and Rose (1966) had revealed that certain yeasts reproduce in the internal parts of sugarcane. Scarr (1951) had found that there are two species of osmophilic yeasts namely, $S$. rouxii and $S$. mallis which were found in raw sugars. deWhalley and Scarr (1947) reported that Saccharomyces cerevisiae (common brewer's yeast) are used to proliferate and undergo fermentation in high density sucrose solution where only true osmophilic yeasts remain active. In sugarcane, most common yeast is Zygosaccharomyces rouxii, although other species of Zygosaccharomyces and species of Pichia, Candida, Dekkeromyces and
Endomycopsis have been reported (Tilburry, 1968; Skole et al., 1977). Yeasts may be present under sheaths of sugarcane where they survive and reproduce (Bevan and Bond, 1971). The presence of bacteria not only deteriorates sugarcane and affects yield but also affects its fodder quality. Certain yeasts may develop in anaerobic conditions and have the capability to survive at lower $\mathrm{pH}$ of 3.5. Even lactic acid bacteria may not inhibit growth of such yeasts (Kung et al., 2003). The presence of yeasts in cane leads to formation of ethanol (from soluble sugars), carbon-dioxide and water (Reis et al., 2004). Yeasts were more profusely found in sugarcane juice and causes difficulties like souring that lead to low sugar recovery and high alcohol formation. During the processing of cane into sugars, xerophilic yeasts were predominant and their recontamination occurs in storage tanks as well as on wet sugar residues that maintain their proliferation in processing lines. Due to the poor hygiene of the equipments in the sugar mills, these yeasts were reported to be increased, viz., about $10^{6}$ yeasts per g (Tilbury, 1980). Among these, many were thermo-tolerant when the conditions were same (Barwald and Hamad, 1984; Anderson et al., 1988). During vacuum pan crystallization of cane processing in sugar mills, these microbes are even not destroyed. The survivability of yeasts was difficult in the diffuser as well as at clarified stage of sugar processing. But these microbes were able to survive the evaporation stage of sugar processing as they have the capability of tolerating high temperatures by undergoing into sporulated form. After this step of evaporation, these microbes were not only able to survive but rather it proliferates at higher rate in sucrose solution as the environment of this solution is favorable (Antier, 1996).

The moulds and fungi play crucial role in sugars that are stored for longer periods. 


\section{Leuconostoc sp.}

Leuconostoc sp., is a soil borne lactic acid bacterium which produces mucous rich colonies inside sugarcane stalk or in sucrose rich juices. This bacterium is the major microorganism which is responsible for low sugar recovery of many sugar mills. As it is soil borne bacterium, it is present in the rhizospheric region of the cane roots. The number of this bacterium varies up to $5 \times 10^{3} /$ gram (Tilbury, 1971). The invasion of these bacteria begins as soon as cane is harvested and with the increase in time lag after harvest these bacteria further proliferates (Fig. 2). On finding its favorable conditions these bacteria forms nodular colonies (Solomon et al., 2000) and especially during heavy rainfall these further proliferate at a higher pace (Misra et al., 2016).

Occurrence of these lactic acid are relatively more in burnt canes but as the time increases after burning their number further accelerates (Eggleston et al., 2008). However, it is interesting to know that there is no change in the frequency of Leuconostoc sp. before and after burning of cane (Bevan and Bond, 1971). It is also been reported that as the time period after harvest increases the number of these bacteria were found to increase further thereby leading to low sugar recovery (Singh et al., 2015; Misra et al., 2016a; 2016b; 2016c; 2016d; Kumar and Singh, 2012). There are various sites from where these bacteria can easily enter into the sugarcane stalk, a place where these bacteria find favorable growth and proliferation conditions. These are:

i. Infected cutting blades in harvesterchoppers

ii. Juice soaked mud in chopping boxes (Bevan and Bond, 1971).

iii. The cuts, bruised ends and fractures in canes facilitate the entry of Leuconostoc $s p$. and other acid or mucous producing bacteria (Egan, 1971).

iv. Over burning of canes destroys the protective wax layer, leading to rind and cracks formation that helps in oozing out juice by destroying stalk of sugarcane. Thus, providing favorable conditions for this bacterium to attack and multiply (Irwine, 1981).

v. Harvested canes kept in open fields (Fig 3a).

vi. Growth cracks on sugarcane also helps in facilitating its growth (Fig. 3b).

Migration of this bacterium in sugarcane stalk is possible within ten minutes after harvest to 7.5 centimeters. The passive movement helps them in travelling inside the vascular bundles to parenchyma cells where these bacteria multiply causing more sucrose losses in cane stalk by production of invert sugars, lactic acids and more frequently a polysaccharide known as dextran. Such canes affected with these bacteria are termed as sour cane (Tilbury, 1968) and the deterioration is termed as bio-deterioration. Besides, being invaded through damaged parts or through contaminated equipments in the fields, these bacteria may invade even during the sugar processing in mills mainly on the ends of the milling train irrespective of the variation in temperatures at both the sides. It is known that these bacteria prefer to grow and reproduce at cooler environment but they are even found in the last step of processing clinging to the sugar molecules where the temperature is high $\left(75^{\circ} \mathrm{C}\right)$. Since these bacteria survives even under high temperatures these are also founds in mixed juice tanks where it is being reported that tapioca like grains are formed due to the symbiotic association between this bacterium and other two bacteria, namely Pichia or Torula and small rod shaped bacteria (Shrivastava and Kumar, 2012). The contamination and survivability of these 
bacteria does not stop here. Chena and Chou (1993) had showed that these are also found on the top of the storage tanks of sugar syrup besides being normally restricted. Antier (1996) had showed that the scum formation and decrease in brix value supported the growth of these bacteria. The former facilitate the soluble oxygen due to the increase surface area coming into contact with air. This bacterium has the capability of converting sucrose into dextran using dextrasucrase as an enzyme (Fig. 4). There is speedy formation at the time of heavy rainfall when this bacterium proliferates rapidly (Anon, 1993).

\section{Difficulties occurred by microorganisms in sugar processing's}

There are various steps where occurrence of microorganisms is more prevalent which in turn causes number of problems in cane processing. During the post-harvesting step leading to processing of sugar favors proliferation of Leuconostoc sp. that creates problems like souring of cane, dextran production and low sugar recovery. At crushing and extraction step, three microorganisms, viz., Leuconostoc, Enterobacter and Yeasts were more profusely found and cause difficulties like souring that leads to low sugar recovery and high alcohol formation. Although at clarification step, there were no microorganisms being found particularly yet dextran formation that occurred during post-harvesting step results in poor clarification. The production of dextran in sugar mills by the presence of Leuconostoc sp. causes number of problems, particularly during refining of sugars (Khalifah, 2001) which are as follows:

a. Viscous juice: It increases the juice viscosity due to which rate of filtration, evaporation, flocculation and mud settling gets affected. Increase in viscosity lowers the heat exchange rate that lowers the evaporation efficiency thereby showing slow crystal growth.

b. Clarification process: It makes clarification process poor as dextran molecules act as neutral or uncharged colloid particles that causes blockage of charged particles.

c. Crystallization: Sugar crystals get elongated as it prevents specific crystal growth leading to retardation of its speed (Kitchen, 1988; Morel, 1991; Vaccari et al., 1999, Muller, 1981)

d. Scaling: Presence of dextran increases in amount of organic acids, thus creating scaling problem that requires more heating time during evaporation process.

e. Viscous syrups: Increase in syrups viscosity and massecuites, causes slow filtration rate.

f. Formation of Molasses: More reducing sugars are formed that leads to increase in purity of molasses.

g. Dextran formation: Sucrose recovery gets highly affected. Due to presence of dextran, reduction in sucrose recovery leading to huge losses during late milling. Besides it, due to its presence erroneous pol reading in sugar factory is observed. The pol becomes affected in varying degree from juice through syrups to sugar leading to chemical control distortion.

h. Elongated sugar crystals formation: Excess nucleation formation of elongated crystals of sucrose, which affects its marketability (this occurs only when the dextran contains more than $84 \%$ of $1-6$ linkages).

i. The loss of time and capacity in process involving a loss of steam, especially in the factories having power co-generation projects. 
On an overall basis, this leads to heavy economic losses to sugar industries viz., higher payment to the farmers due to false polarimeter value (Cerutti et al., 2000) that occurred due to dextro-rotatory property of dextran having higher specific rotation value than sucrose (Wilson, 1996; Paton et al., 1993; Morel, 2005).

It has been stated in sugarcane juice, one part per million (ppm) units of dextran create a loss of 0.0025 pounds of raw sugar in reference to its production in per ton of sugarcane (Day, 1994). At evaporation, crystallization and centrifugation step, thermophilic bacteria (Bacillus starothermophilus and B. coagulans) were more found (McMaster and Ravno, 1977) that ferment invert sugars to lactic acid (95\%) and also leads to formation of formic acid, acetic acid and glycolic acid (McMaster 1975, Oldfield et al., 1947a).

Besides this, the sugar could also be contaminated with microorganisms (Xerophilic moulds, Z. rosaxii) through contaminated equipments. This leads to formation of invert sugars, production of acids thus leading to loss in sugar.

Last but not the least step of sugar processing, the themophilic spores get introduced into the final product. Studies had also revealed that presence of the microbes leads to low purity of sugars with higher brix value responsible for higher molasses formation (Clarke, 1980; Foster, 1980). Recontamination with slime producing bacteria like Leuconostoc sp. is found in places of mills where hygiene is not maintained. Also, contamination of baggase with these microorganisms during sugar processing permits micro-organisms growth and proliferation (Klaushofer et al., 1988).

\section{Control measures for invasion of microorganisms}

Several measures are being taken to control the invasion of microorganisms in sugarcane. Following control measures are to be considered:

1. Clean harvested canes: Harvested cane should be free from mud and trash and should be loaded in a proper manner in the trucks so that no fractures or damages occur in sugarcane stalk which helps in preventing the further invasion sites for microorganisms.

2. No delay in clarification step after extraction: Clarification process should be immediately followed by extraction step.

In this process, addition of lime takes place that increases the $\mathrm{pH}$ of the juice to about 8.0 and rapid heating to $80-100^{\circ} \mathrm{C}$ for destruction of microorganisms. This step in sugar processing reduces the growth and proliferation of microorganisms by $99.99 \%$. Although the microorganisms are being killed in this process yet dextran and mesophilic or thermophilic spores were not killed (Chen and Chung, 1993).

3. Maintenance of high temperatures in diffuser: In diffusion plants, during sugar processing maintaining high temperature is an efficient way for controlling microorganisms.

4.Cleaning of the equipments and maintenance of hygiene: Sugar processing requires good hygiene for controlling microorganisms. Maintenance of this by adequate awareness for cleaning the equipments is required for avoiding the buildup of microorganisms like slime producers (Klaushofer et al., 1998). 
Table.1 Association of microorganisms in sugar processing

\begin{tabular}{|c|c|c|c|}
\hline $\begin{array}{l}\text { S. } \\
\text { No. }\end{array}$ & Microorganisms & Site of invasion & $\begin{array}{c}\text { Formation of products from sucrose } \\
\text { deterioration }\end{array}$ \\
\hline 1 & Xanthomonas & \multirow[t]{3}{*}{ Cane } & \multirow[t]{2}{*}{ Organic acid } \\
\hline 2 & Aerobacter & & \\
\hline 3 & $\begin{array}{l}\text { Brevibacterium } \\
\text { imperiale }\end{array}$ & & $\begin{array}{l}\text { Red pigment } \\
\text { Organic acid }\end{array}$ \\
\hline 4 & Aspergillus fumigatus & Air & Organic acid \\
\hline 5 & $\begin{array}{l}\text { Lactobacillus } \\
\text { fermentum }\end{array}$ & \multirow[t]{3}{*}{$\begin{array}{l}\text { Primary juice, } \\
\text { Mixed juice }\end{array}$} & Lactic acid \\
\hline 6 & L cellubioscus & & Lactic acid \\
\hline 7 & $\begin{array}{l}\text { Leuconostoc } \\
\text { mesenterioides }\end{array}$ & & $\begin{array}{l}\text { Lactic acid, } \\
\text { Dextran }\end{array}$ \\
\hline 8 & $\begin{array}{l}\text { Leuconostoc } \\
\text { dextranicum }\end{array}$ & Mixed Juice & Dextran \\
\hline 9 & Pichia spp. & \multirow[t]{6}{*}{ Mixed Juice } & \multirow[t]{5}{*}{ Fermentation } \\
\hline 10 & Hansenula spp & & \\
\hline 11 & Saccharomyces spp & & \\
\hline 12 & Pleocyta sacchari & & \\
\hline 13 & Candida spp. & & \\
\hline 14 & Bacillus spp & & Levan production \\
\hline
\end{tabular}

Fig.1 Growth factors of microorganisms in harvested sugarcane

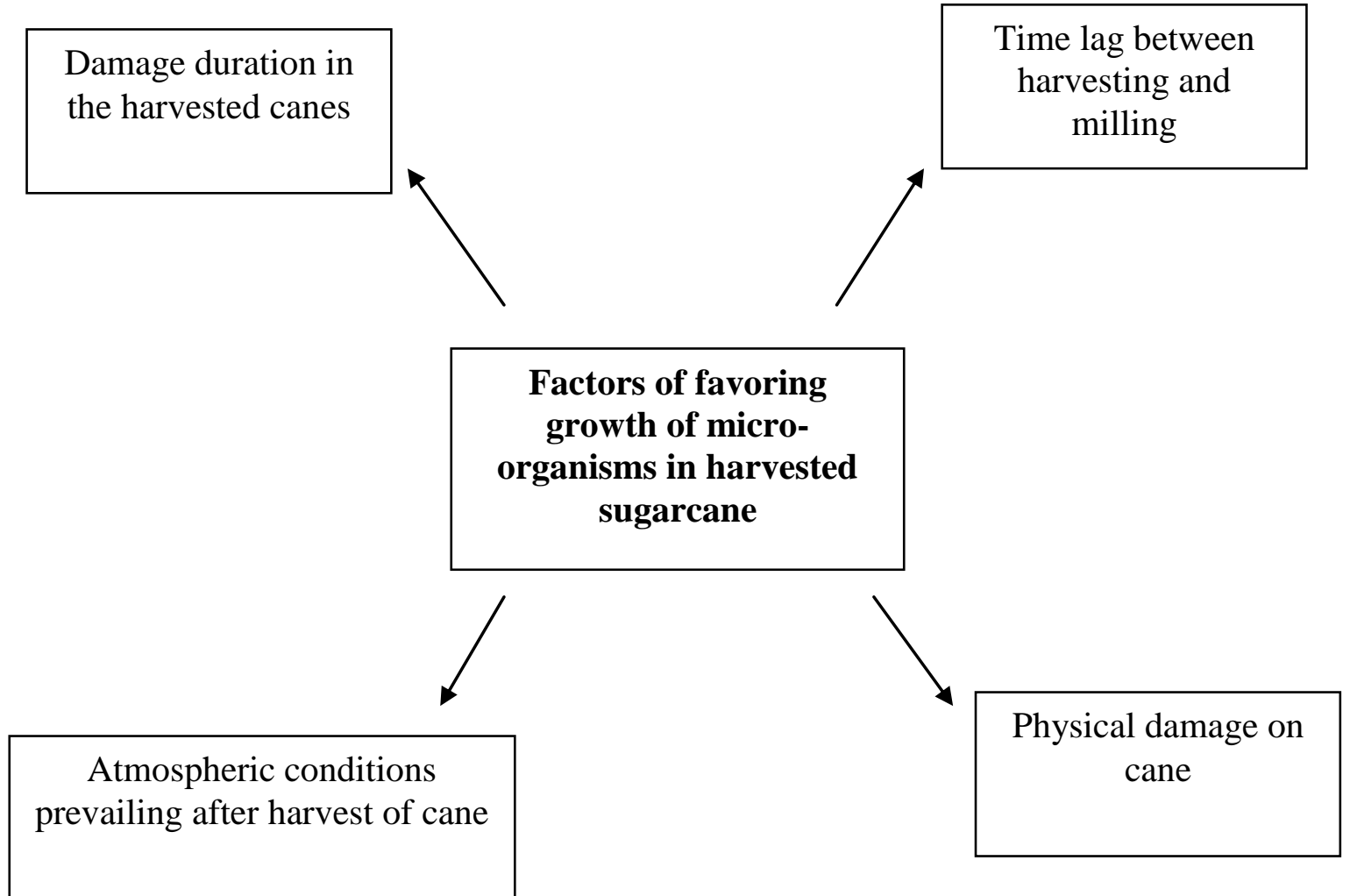


Fig.2 Isolation of Leuconostoc bacteria in stale cane and fresh cane juice

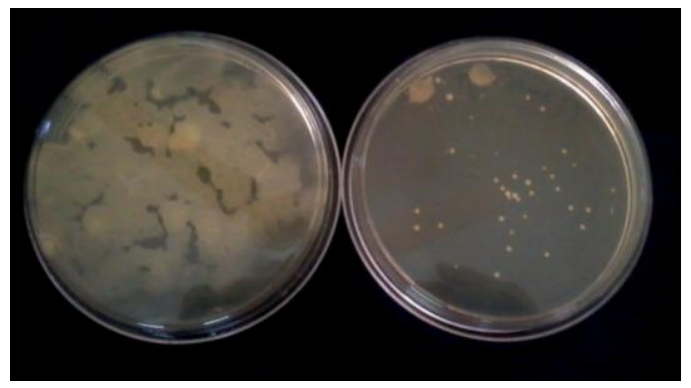

Fig.3 Possible infestation regions of Leuconostoc sp. in sugarcane (a) cut ends of harvested sugarcane (b) cracks in sugarcane at lower internodes

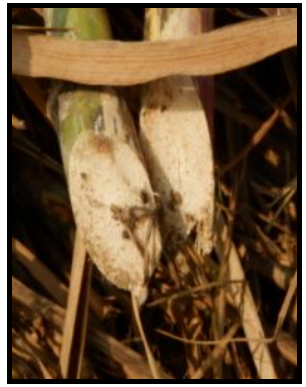

(a)

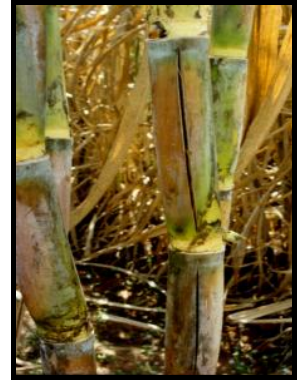

(b)

Fig.4 Biochemical changes induced by Leuconostoc sp. infestation during post-harvest deterioration of sugarcane

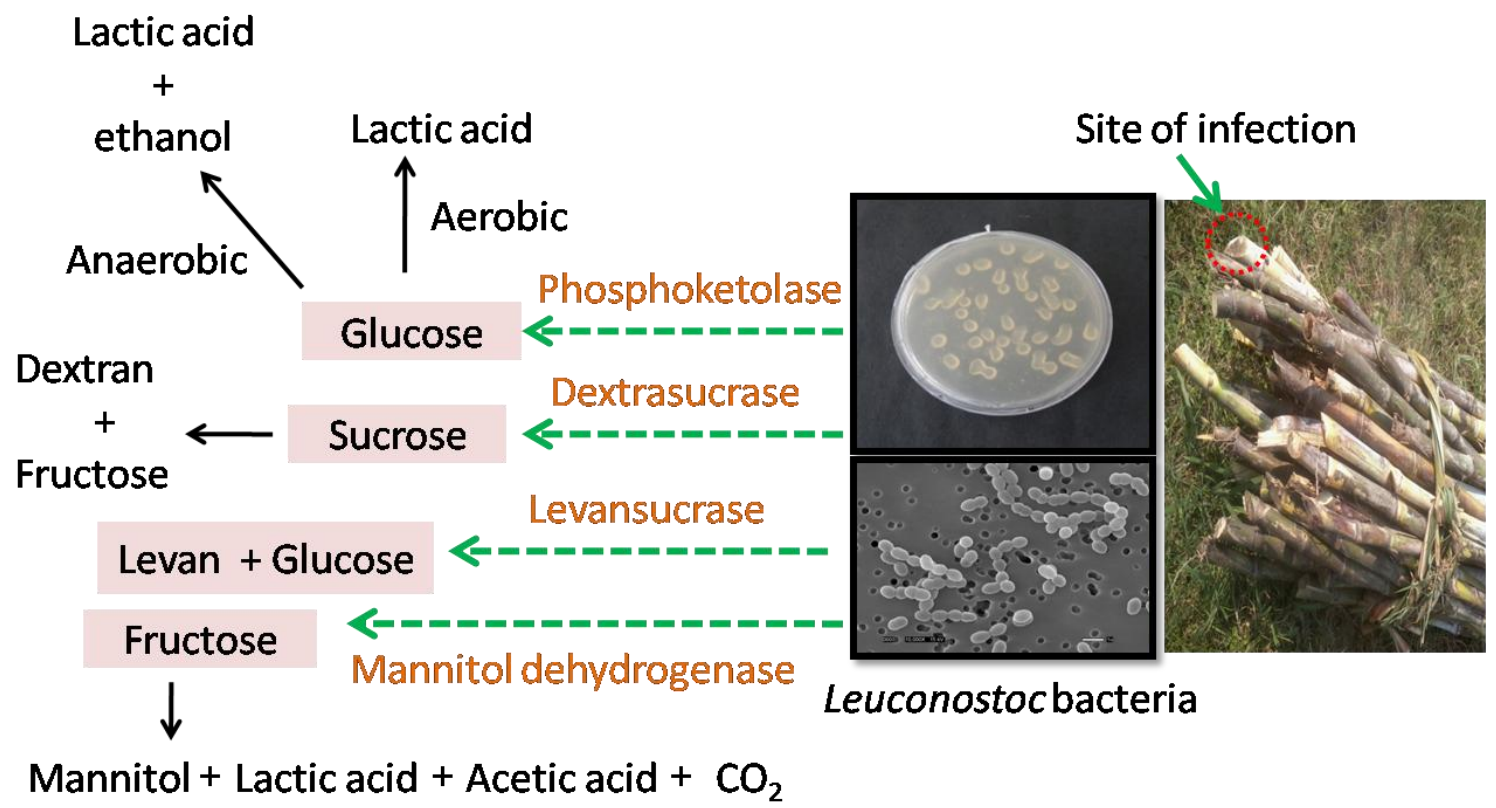

5. Application of mill sanitizers on harvested canes: Number of effective mill sanitizers are being used such as halogen based biocides, quaternary ammonium compounds, 
formulation of benzalkolium chloride and sodium metasilicate, dithiocarbamate based biocides, Polmax ESR, Polmax Supreme, etc.

In conclusion, microorganisms especially mucoid producing organisms namely, Leuconostoc, Xanathomonas and Aerobacter, are prevalent leading to production of acids and dextran like materials. The formation of these materials is indicative of sucrose deterioration in sugarcane juice.

These microbial invasions begin from the time cane is harvested and is further accentuated as time period increases. Besides, there is higher probability of invasion of them even during cane and sugar processing in sugar mills. Occurrence of microorganisms in sugarcane not only deteriorates sucrose but even causes problems in sugar processing. Studies on this aspect in ancient times showed that there is no practical control is possible for inhibiting the growth of microorganisms. The only way which might be possible is the low time lag between harvesting and milling. But later on studies had tried applications of several chemicals on harvested sugarcane to inhibit the growth of these microbes. However, they were successful to some extent but still complete control over microorganisms has not yet achieved. There is still a need of further study to be performed on this aspect so as to minimize the sucrose losses occurring due to the microbial growth and proliferation.

\section{References}

Anderson, P.J., McNeil, K.E. and Watson, K., 1988. Isolation and identification of thermo tolerant yeasts from Australian sugar cane mills. J. F. Gen. Microbiol., 134: 1691-1698.

Antier, P. 1996. Microbiological Control in a Cane Sugar Mill: Implications on Sugar Quality and Losses. Proc. S. Afr. Sug. Technol. Ass., 185-188.
Barwald, G. and Hamad, S.H. 1984. The presence of yeasts in Sudanese cane sugar factories. Zuckerind, 109:1014-1016.

Bevan, D. and Bond, J. 1971. Micro-organisms in field and mill-A preliminary study. Proc. Qd. Soc. Sugar Cane Technol. Thirty-eighth Conf., 137-143.

Cerutti de Guglielmone, G.C., Diez, O., Cardenas, G. and Oliver, G. 2000. Sucrose utilization and dextran production by Leuconostoc mesenteroides isolated from the sugar industry. Sug. J., 36-41.

Chen, J.C.P. and Chou, C.C. 1993. Microbiological control in sugar manufacturing and refining. In: Chen JCP and Chou CC, eds. Sugarcane Handbook, John Wiley and Sons Inc., New York.

Day, D.F. 1994. Dextran induced sugar loss to molasses. J. American Society of Sugar Cane Technologists, 14: 53-57.

Duncan, C.L. and Colmer, C.L. 1964. Coliforms associated with sugarcane plants and juices. Appl. Micro., 12(2): 173-177.

Egan, B.T. 1971. Post-harvest deterioration of sugar cane. Bur. Sug. Exp. Stns. Qd.

Eggleston, G., Morel du Boil, P.G. and Walford, S.N. 2008. A review of sugarcane deterioration in United States and South Africa. Proc. S. Afr. Sug. Technol Assoc., 81: 72-85.

Gandra, E.A., Reitembach, A.F., Bolanho, B.C., Guimaraes, J.S., Gandra, T.K.V. et al. 2007. Microbiological conditions of cane stocks traded in Umuarama (PR). Revista Brasileira de Tecnologia Agroindustrial, 1(2): 61-69.

Irvine, J.E. 1981. Sugarcane. Saccharum hybrids. p. 211-229. In: McClure, T.A. and Lipinsky, E.S. (eds.), CRC handbook of biosolar resources. vol. II. Resource materials. CRC Press, Inc., Boca Raton, F. L.

Khalifah, M.A. 2001. Effect of dextran on sugar cane quality and raw sugar manufacture dissertation, Assiut University, Egypt.

Kitchen, R.A. 1988. Polysaccharides of sugarcane and their effects on sugar 
manufacture. Chapter 14, In: Chemistry and Processing of Sugar beet and sugar cane. Elsevier Science Publishers BV, Amsterdam, the Netherlands. pp 208-235. Klaushofer, et al. 1988.

Kopoloffs. 1920.

Kulkarni, V.M. and Kulkarni, S.S. 1987. Microbiology of sugar manufacturing process. Proc. Deccan Sugar Technologists Assoc., 37: M37-M43.

Kumar, A. and Singh, R. 2012. Microorganism in sugarcane and sugar processing, Impact and Remedial actions to eliminate its effect on recoverable sugar. Proc. $71^{\text {st }}$ Annual Convention of Sugar Technologists Association of India, 5061.

Kung Jr., L., Taylor, C.C., Lynch, M.P., Neylor, J.M. 2003. The effect of treating alfalfa with Lactobacillus buchneri 40788 on silage fermentation, aerobic stability, and nutritive value for lactating dairy cows. $J$. Dairy Sci., 86: 336-343.

Mayeux. 1960.

McMaster, L. 1975. Thermophilic bacteria associated with cane sugar diffusion process. M.Sc. Thesis, University of Natal, Durban, South Africa.

McMaster, L. and Ravno, A.B. 1977. The occurrence of lactic acid and associated microorganisms in cane sugar processing. Proc. Int. Soc. Sugar Cane Technol., 16:1-15.

Misra, V., Prajapati, C.P., and Ansari, M.I. 2016d. Efficacy of chemicals reducing the growth of Leuconostoc bacteria in harvested stale cane. STAI Proceeding $74^{\text {th }}$ Annual Convention held at New Delhi, on $28^{\text {th }}-30^{\text {th }}$ July, 264-272.

Misra, V., Solomon, S., and Ansari, M.I. 2016c. Effectiveness of chemical treatments over harvested stale cane against Leuconostoc bacteria. International congress on postharvest Technologies of Agricultural Produce for sustainable Food and Nutritional Security held at Integral University, Lucknow on $10^{\text {th }}-12^{\text {th }}$ November; 292

Misra, V., Solomon, S., and Ansari, M.I., 2016b. Impact of drought on post-harvest quality of sugarcane crop. Adv. Life Sci., 20(5): 9496-9505.

Misra, V., Solomon, S., Shrivastava, A.K., Shukla, S.P. and Ansari, M.I. 2016. Post Harvest sugarcane deterioration: Leuconostoc and its effect. J. Functional and Environ. Biol., 6(1): 1-7.

Misra, V., Solomon, S., Singh, P. Prajapati, C.P. and Ansari, M.I. 2016a. Effect of water logging on post harvest sugarcane deterioration, Agrica, 5(2): 119-132.

Morel du Boil, P.G. 1991. The role of oligosaccharides in crystal elongation. Proc. S. Afr. Sug. Technol. Assoc., 65: 171-178.

Morel du Boil, P.G. 2005. A review of five seasons monitoring of $\mathrm{MJ}$ and VHP dextran using specific enzyme HPAEC methodology. SMRI Technical Report.

Muller, 1981.

Nunez and Colomer. 1968.

Oldfield, J.F.T., Dutton, J.V. and Shore, M. 1947a. Effects of thermophillic activity in diffusion on sugarbeet processing. Part I. Int. sugar J., 76: 260-263.

Paton, N.H., Player, M.R., Urquhart, R.M. and Duong M. 1993. The use of near infra red polarimetry to determine the polarisation of raw sugar. Zuckerind, 118: 705-709.

Prati, P. 2004. Life-of-shelf study prepared by drink garapa partially clarificada-mix stabilized and juice natural passion. Universidade Estadual de Campinas, Brazil.

Reis, R.A., Siqueira, G.R., Bernardes, T.F. 2004. Experiência da UNESP Jaboticabal na ensilagem da cana-de-açúcar. I Reunião Técnica sobre Silagem com Cana-de-açúcar. EMBRAPA Pecuária Sudeste, pp 13.

Scarr, M.P. 1951. Osmophilic yeasts in raw beet and cane sugars and intermediate sugar refining products. J. Gen. Microbiol., 5: 704-708.

Scarr, M.P. and Rose, D. 1966. Study of osmophilic producing invertase. J. Gen. Microbiol., 45: 9-16.

Shehata, A.M., El-Tabey. 1960. Yeasts isolated 
form sugar cane and its juice during the production of Aguardente de Cana. Appl. Microbiol., 8(2): 73-76.

Sherwood, I.R. and Hines, W.J. 1950. Proc. Int. Soc. Sugar Cane Technologists, 7th Congr., I 591-607.

Silva O. Carine, Gallo, A.F., Bomdespacho, Q.L., Kushida, M.M. and R. Petrus, R. R. 2016. Sugarcane Juice Processing: Microbiological Monitoring. J. Food Processing and Technol., 7(8) DOI: 10.4172/2157-7110.1000607.

Singh, P., Solomon, S., Prajapati, C.P., Kumar, S., Misra, V. and Chandra, A. 2016. Deterioration of fresh and stale cane juice at high ambient temperature in relation to expression of invertases and the growth of Leuconostoc sp. Agrica, 4: 79-85.

Skole, et al. 1977.

Solomon, S. 2000. Post harvest cane deterioration and its milling sequences. Sugar Tech., 2(1 \& 2): 1-18.

Solomon, S. 2009. Post-harvest deterioration of sugarcane. Sugar Tech., 11(2): 109-123.

Solomon, S., Banerji, R., Shrivastava, A.K., Singh, P., Singh, I., Verma, M., Prajapati, C.P. and Sawnani, A. 2006. Post-harvest deterioration of sugarcane and chemical methods to minimize sucrose losses. Sugar Tech., 8(1): 74-78.

Suman, A., Solomon, S., Yadav, D.V., Gaur, A. and Singh, M. 2000. Post-harvest loss in sugarcane quality due to endophytic micro-organisms. Sugar Tech., 2(4): 2125.

Tilbury, R.H. 1968. Biodeterioration of harvested sugarcane, in biodeterioration of materials. Microbiological and allied aspects (eds. A H. walters and J. J. Elphick), Elsevier, Amesterdam, pp.71730.

Tilbury, R.H. 1970. Biodeterioration of harvested sugar cane in Jamaica. Ph.D. Thesis, Univ. of Aston, Birmingham, England.

Tilbury, R.H. 1971. Dextran and dextranase. Proc. Int. Soc. Sugar Cane Technol., 14: 1444-1458.

Tilbury. 1980.

Vaccari, G., Sgualdino, G., Tamburini, E., Dosi, E., Mantovani, G. and Aqililano, D. 1999. Contribution of kestoses to the morphological modification of sucrose crystals. Proc. Int. Soc. Sugar Cane Technol., 23(1): 147-156.

Whalley, de H.C.S. and Scarr, M.P. 1947. Microorganisms in raw and refined sugars and intermediate products. Chem. Industr., 351.

Wilson, T.E. 1996. A comparison of raw sugar polarization methods - high wavelength (NIR) vs ICUMSA GS1/2/3-1 (1994). Int. Sugar J., 98: 169-174.

\section{How to cite this article:}

Varucha Misra, A.K. Mall, A.D. Pathak, S. Solomon and Ram Kishor. 2017. Microorganisms affecting Post-Harvest Sucrose Losses in Sugarcane. Int.J.Curr.Microbiol.App.Sci. 6(7): 25542566. doi: https://doi.org/10.20546/ijcmas.2017.607.361 